\title{
The Improvements of Mathematical Problem Solving Ability of Junior High School Students through Modify-Action, Process, Object, Schema (M-APOS) Learning Model and
}

\section{Problem Based Learning Model}

\author{
Santy Setiawati ${ }^{1}$ \\ Department of Mathematics Education \\ Indonesia University of Education (UPI) \\ Bandung, Indonesia \\ santyss12@gmail.com
}

\author{
Elah Nurlaelah \\ Department of Mathematics Education \\ Indonesia University of Education (UPI) \\ Bandung, Indonesia \\ elah_nurlaelah@upi.edu²
}

\author{
Bambang Avip Priatna ${ }^{3}$ \\ Department of Mathematics Education \\ Indonesia University of Education (UPI) \\ Bandung, Indonesia \\ bambangavip@yahoo.com ${ }^{3}$
}

\begin{abstract}
This study is motivated by the fact that students' mathematical problem solving abilities in junior high school are low. The purposes of this study are therefore (1) to find out whether there is a difference in mathematical problem solving abilities improvements between students who acquired learning using Modify-Action, Process, Object, Schema (M-APOS) learning model and those who acquired learning using Problem Based Learning (PBL) model; (2) to know students' response toward mathematics learned using M-APOS learning model and PBL model. The research method was quasi experimental method with non-equivalent control group. Study population was all seventh graders of a junior high school in Bandung for the academic year 2014/2015 and the samples for this study were students from two classes at the school in which one class was MAPOS class and the other class was PBL class. The study data were derived from mathematical problem solving abilities test, questionnaires and observation forms. The results showed that (1) there is a difference in improvements in mathematical problem solving abilities between students who acquired learning using M-APOS learning model and those who acquired learning using PBL model; (2) almost all students from both sample classes show positive response toward mathematics learned using both M-APOS learning model as well as PBL model.
\end{abstract}

Keywords-M-APOS learning model; Problem Based Learning model; Mathematical problem solving ability

\section{INTRODUCTION}

Five mathematical abilities that students need to have according to National Council of Teachers of Mathematics
(NCTM) consist of "problem solving, communication, connection, reasoning and representation" [1]. The importance of problem solving abilities is also shown in official school curriculum of Indonesia known as 2013 Curriculum which placed problem solving within basic competencies included in Content Standards as stated in Minister of Education and Culture Regulation Number 64 of 2013 (Permendikbud Nomor 64 Tahun 2013). Within these basic competencies, it is stated that "Students are expected to show logical, critical, analytical, precise, thorough, responsible, responsive and persistent attitudes in problem solving" [2].

The aforementioned stance affirms that problem solving is an important part of learning mathematics. Turmudi [3] defined problem solving as "A process that involves a task in which the solution method is unknown. To know the solution, students need to use their prior knowledge and through this process they can expand their new mathematical knowledge" [3].

The result of the preliminary study done through mathematical problem solving ability test which consisted of proportion topic that had been done by the writers toward 31 eight graders at SMPN 7 Bandung in the academic year of $2014 / 2015$ showed that only four students answered the problems correctly, even though strategies used by these students were ambiguous. In response to the aforementioned problem, students need to be given help so that they can solve mathematics problems, because problem solving is a process 
in learning. A learning model that allows students to build their own understanding is Modify-Action, Process, Object, Schema (M-APOS) learning model. Further, one of the learning models suggested by 2013 Curriculum to be applied is Problem Based Learning (PBL) model.

M-APOS learning model is a learning model based on Action, Process, Object, Schema (APOS) theory that has been modified. Nurlaelah indicated that "Learning using APOS theory emphasizes on knowledge gained through preliminary activities" [4]. Based on that, preliminary activities in learning using APOS theory comprise of using computer program in a computer laboratory which is different than M-APOS learning model. In M-APOS, the preliminary activities comprise of student assignments. M-APOS learning model is "A learning model that utilizes assignments arranged in worksheets used as students' activities guidelines within APOS learning model frameworks" [4].

The implementation of M-APOS learning model is similar to the implementation of APOS theory, in which they both use a cycle that consisted of activity, class discussion and exercise (ACE). In implementing APOS learning model, students are given an assignment during activity phase before learning content is taught. The purpose of providing an assignment is so that students may have sufficient time to explore learning content. Next, during the class discussion phase, students perform group discussion to solve problems using concepts that have been reviewed during the preliminary assignment. In the last phase, students work on exercise to sharpen learning content.

Barrow defined Problem Based Learning as "A learning process derived from a process that leads to a resolution comprehension of a problem" [5]. Steps in PBL model are: (1) orient students toward problem (2) organize students (3) guide individual and group investigation (4) develop and present work result (5) analyze and evaluate problem solving process [2]. In this study, M-APOS leaning model will be compared to PBL model in terms of the increase in students' mathematical problem solving ability.

In addition to learning, students' response toward mathematics and mathematical learning process is important to note. The expectation is that students' response toward mathematical learning process provides positive impression, even though there are students who show negative impression. Students' response greatly influences mathematical learning achievement including improvement in mathematical problem solving abilities. Therefore, it is important to conduct a study about student's response toward M-APOS learning model and PBL model.

This study examines the following questions: (1) is there a difference in mathematical problem solving ability improvements between students who acquired learning using M-APOS learning model and those who acquired learning using PBL model?; (2) what is students' response toward mathematics learned using M-APOS learning model and PBL model?

\section{RESEARCH METHOD}

Research method used in this study was quasi experimental. "Since the subjects are not randomly grouped, but rather accept the subject condition as determined" [6]. The design used in this study was non-equivalent design because the subjects were not randomly grouped. Nonequivalent control group's design consisted of pre-test, different treatments and post-tests. This study took into account two experimental groups which were experimental group 1 and experimental group 2. Experimental group 1 learned mathematics using M-APOS learning model and experimental group 2 learned mathematics using PBL model.

Population in this study was all seventh grade students of SMPN 7 Bandung within the academic year of 2014/2015, which consisted of total 8 classes. For study purposes, two classes were selected, which were class VII-D as experiment class 1 acquired learning using M-APOS learning model whereas class VII-F as experiment class 2 acquired learning using PBL model. Samples were selected using sampling purposive technique which means "to define samples with certain considerations" [7].

Instrument used in this study was mathematical problem solving ability test. The topic in this test was proportion, with the main discussion are the concept of proportion, direct proportion, indirect proportion and scale as proportion.

\section{RESULTS AND DISCUSSION}

Mathematical problem solving ability of students in the MAPOS class and PBL class, is not having any difference at the beginning of the learning. Furthermore, analysis of data on the post-test to determine whether students in the M-APOS class and PBL class experience a difference in improvements in mathematical problem solving ability when the learning was given. The output of the average test of the data post-test presented in Table I.

\section{TABLE I. OUTPUT OF THE AVERAGE TEST OF THE DATA POST-TEST}

\begin{tabular}{|l|l|}
\hline & \multicolumn{1}{c|}{ Post tes } \\
\hline Mann-Whitney U & 296.000 \\
\hline Wilcoxon W & 792.000 \\
\hline Z & -2.608 \\
\hline Asymp. Sig. (2-tailed) & .009 \\
\hline
\end{tabular}

Based on the table I, the value of a significant (two-tailed) was $0.009<\alpha$, with $\alpha=0.05$, then $\mathrm{H}_{0}$ is rejected. It shows that the average of the data post-test class M-APOS is having difference significantly from the class of PBL.

Analysis of the data used to determine the average normalized gain in improvements in students' mathematical problem solving ability. The average normalized gain is calculated using the formula [8] as follows.

$$
\langle\mathrm{g}\rangle=\frac{\text { Skor posttest }- \text { Skor pretest }}{\text { Skor maksimum-Skor pretest }}
$$

Average normalized gain M-APOS class and PBL class distribution is not normal. Because there are two classes of research distribution is not normal, then the next test is to use nonparametric statistics, namely the Mann-Whitney test. 
The output of the analysis of the average normalized gain test are presented in Table II.

TABLE II. OUTPUT OF THE ANALYSIS OF THE AVERAGE NORMALIZED GAIN TEST

\begin{tabular}{|l|c|}
\hline & Indeks Gain \\
\hline Mann-Whitney U & 297.000 \\
\hline Wilcoxon W & 793.000 \\
\hline Z & -2.587 \\
\hline Asymp. Sig. (2-tailed) & .010 \\
\hline
\end{tabular}

Based on Table, the value of a significant (two-tailed) was $0,010<\alpha$, with $\alpha=0.05$, then $\mathrm{H}_{0}$ is rejected at significance level $\alpha=0.05$. This means, there is a difference significantly increased students' mathematical problem solving ability among the learning gained by M-APOS learning model and Problem Based Learning. The composition of interpretation average normalized gain for each class can be seen from the table III below.

TABLE III. THE COMPOSITION OF INTERPRETATION AVERAGE NORMALIZED GAIN

\begin{tabular}{|c|c|c|c|c|}
\hline Classes & $\begin{array}{c}\text { Interpretation } \\
\text { of Indeks Gain }\end{array}$ & $\begin{array}{c}\text { The } \\
\text { number of } \\
\text { students }\end{array}$ & Percentage & Average \\
\hline \multirow{2}{*}{$\begin{array}{c}\text { MP- } \\
\text { APOS }\end{array}$} & High & 5 & $16,13 \%$ & \multirow{2}{*}{0,39} \\
\cline { 2 - 4 } & Medium & 14 & $45,16 \%$ & \multirow{2}{*}{0,26} \\
\cline { 2 - 4 } PBL & Low & 12 & $38,71 \%$ & \\
\cline { 2 - 4 } & High & 0 & $0 \%$ & \\
\cline { 2 - 4 } & Medium & 12 & $38,71 \%$ & \\
\hline
\end{tabular}

Table IV shows the average pre-test, post-test and normalized gain scores of mathematical problem solving ability.

TABLE IV. Average Pre-Test, Post-Test and Normalized Gain SCORE OF MATHEMATICAL PROBLEM SOLVING ABILITY

\begin{tabular}{|c|c|c|c|}
\hline Class & Pre-test & Post-test & Normalized gain \\
\hline M-APOS & 12.97 & 23.42 & 0.39 \\
\hline PBL & 10.71 & 18.06 & 0.26 \\
\hline
\end{tabular}

Based on the average normalized gain, It showed that the improvements in mathematical problem solving abilities in $\mathrm{M}$ APOS class was within the medium category. Where as in the PBL class, the improvement was within low category. One of the reasons why both classes showed the results as presented in Table I, was because one of the instrument problems in the mathematical problem solving test was considered hard for the seventh graders. The problem was problem number 4 which comprised solving mathematical open ended question. Problem number 4 is "Ratio between the first number and the second number is $2: 3$. If each number plus 4 , then the ratio becomes $4: 5$. How to determine the result of multiplying the two numbers? What is the result of multiplying the two numbers?".

The solution to the problem needed algebra function, but at the time, the seventh graders had not learned about algebra. As a result, even after students were given problems similar to algebra and after given brief explanation about the topic, students still did not fully comprehend the problems. Based on the post-test results in both M-APOS class and PBL Class, students worked on the problem number 4 without using related mathematical models and explanations that the students provided on the paper were ambiguous.

Even though there was only $29.03 \%$ students in the MAPOS class and $3.22 \%$ students in the PBL class that achieved minimum passing grade, specific improvements in mathematical problem solving abilities were found within students in both groups. These specific improvements can be seen in the M-APOS students who subsequently were used to independently find information and reconstruct their understanding about a concept within sufficient time and to solve problems both individually as well as in group. Branca stated that "Activities classified as problem solving include solving simple word problems in the standard text book, solve non-routine problems or puzzle, using mathematics to solve real life problems, develop and examine conjecture" [9].

The first phase in M-APOS model was activity phase in which learning begun with a teacher randomly selected students to present the results of their worksheets (Lembar Kerja Tugas), which was about proportion. Before the class started, students had been asked to finish a worksheet that needed to be done at home. Nurlaelah stated that "A learning model that requires students to work on an assignment given in the form of a worksheet that works as a guidance to students' activities within APOS learning model is called modified APOS learning model (M-APOS)" [4]. Worksheet was structured so that students were encouraged to find information about a proportion concept. After that, a number of students were selected to present their results and other students were asked to provide comments. If there were concepts that were not fully understood by students, teachers explained the concepts.

In the discussion phase, the teacher divided students into groups of 3 to 4 students. Teacher distributed discussion worksheet (Lembar Kerja Diskusi) to each student and students finished the worksheet through group discussion. Teacher observed the activities and students' flow of thoughts. In this stage, the teacher found students who made mistakes in planning the solution. As stated by Polya "planning is important to do because when students are able to connect known data to the unknown data, students will be able to finish problem from previous knowledge" [10]. Subsequently, teacher asked students to present their discussion results in front of the class. Other groups that did not get to present, were asked to make comments so that inter-group discussion took place. The last phase was the exercise phase. During this exercise phase, students worked on assignments designed to establish proportion concepts. Exercise was done individually and students who were not able to finish because of the time constraint, were allowed to bring the exercise home as a homework.

In the PBL model, the first phase was students' orientation toward problems. In this phase, learning begun by providing daily problems to the classroom. In this phase, students observed carefully examples from problems that occurred on a daily basis related to the proportion concept. As stated by Arends, "PBL model organizes learning around questions and problems that are socially important and personally 
meaningful for students" [11]. During the second phase which is organizing students, students were divided into smaller groups of 3 to 4 students. The teacher then distributed worksheets and students worked on the worksheets through group discussion.

Next was to guide students in both individual and group investigation. During this phase, teacher guided students in working on worksheets by providing information when students faced difficulties and monitored students' work. At the time when teachers guided students in working on the worksheets, there were students who were still asking about the meanings of the problems on the worksheets. It suggests that there were students who faced difficulties in gaining an understanding about the problems on the worksheet. On the other hand, Polya suggested that "understanding the problem stage needs to be done in the beginning stage of the problem solving process so that students can easily find solutions to the problems asked" [9]. During the development and end result presentation stage, students were welcome to present their discussion results. A group representative presented their discussion results in front of the class. Other groups that did not present were given opportunities to comments and provide ideas. The last stage was to analyze and evaluate the problem solving process. During this phase, students were given problems that needed to be worked on individually to find out the learning results.

In the beginning of the lesson in PBL Class, students were asked to understand a concept through problems given in the class and work on problems in the daily life to establish their own knowledge. As stated by Barrow, "PBL Learning as a lesson gained through an understanding process toward a problem resolution. The problem is first encountered during a learning process" [5]. However, during the implementation of PBL model, students did not have enough room to explore concepts taught in the classroom and students still relied on the teacher in explaining the lessons.

Prabawanto suggested that "Human develop their problem solving abilities based on the cognitive process" [9]. Therefore, both M-APOS students and PBL students showed improvements in their mathematical problem solving abilities because they experienced an acquisition of knowledge. However different learning process provided different impacts to the improvement levels. Therefore, there was a difference in improvement levels between students who acquired learning using M-APOS learning model and students who acquired learning using PBL model. Even so, the average normalized gain for M-APOS class was within the medium range and the $\mathrm{PBL}$ class was within the low range. The implementation of M-APOS model and the PBL model need to be optimized to increase students' mathematical problem solving abilities.

The above data were also supported by the questionnaire results given to both M-APOS and PBL classes to find out about students' response toward the implementations of both M-APOS learning model and PBL model in learning mathematics and their response towards mathematics. The result of questionnaire analysis is presented in Table II.
TABLE V. QUESTIONNAIRE DATA ANALYSIS TOWARD STUDENTS' RESPONSE IN LEARNING MODEL IMPLEMENTATION AND TOWARD MATHEMATICS

\begin{tabular}{|c|c|c|}
\hline Class & $\begin{array}{c}\text { Students' Response } \\
\text { Toward The } \\
\text { Implementation of } \\
\text { Learning Models }\end{array}$ & $\begin{array}{c}\text { Students' } \\
\text { Response Toward } \\
\text { Mathematics }\end{array}$ \\
\hline M-APOS & $90.97 \%$ & $97.42 \%$ \\
\hline PBL & $89.68 \%$ & $90.65 \%$ \\
\hline
\end{tabular}

The questionnaire results from the M-APOS class showed that almost all students gave positive response toward the implementation of M-APOS learning model in mathematics lessons and almost all students gave positive response toward the implementation of PBL model in mathematics lessons. As indicated by Harvey and Smith that "attitude is readiness in consistently responding in positive or negative ways toward an object or a situation" [12].

\section{CONCLUSION}

Learning process using different learning models affects the improvement in students' mathematical problem solving abilities. Therefore, it is concluded from this study that there is a difference in improvements in mathematical problem solving abilities between students who acquired learning using M-APOS learning model and those who acquired learning using PBL model. The results showed that the improvement in M-APOS class is higher than the improvement in PBL class because during the implementation of M-APOS learning model, students were given sufficient time to explore their knowledge. In addition, almost all students from both MAPOS class and PBL class showed positive responses toward mathematics learned using both M-APOS learning model as well as PBL model.

\section{References}

[1] NCTM, Principle and Standards for School Mathematics. Virginia: NCTM, 2000.

[2] Kemendikbud, Materi Pelatihan Implementasi Kurikulum 2013 Tahun 2014. Jakarta: unpublished, 2014.

[3] Turmudi, "Mathematical problem solving," unpublished.

[4] E. Nurlaelah, "Task assignment model conducted in english in improving mathematical communication ability and self-confidence within college students who are teacher candidates," journal of teaching MIPA, vol. 17, number 2, pp. 173-182, October 2012.

[5] M. Huda, Model-Model Pengajaran dan Pembelajaran: Isu-Isu Metodis dan Paradigmatis. Yogyakarta: Pustaka Pelajar, 2014.

[6] E. T. Ruseffendi, Dasar-Dasar Penelitian Pendidikan \& Bidang Non Eksata Lainnya. Bandung: Tarsito, 2010.

[7] Sugiyono, Metode Penelitian Pendidikan (Pendekatan kuantitatif, kualitatif, dan R\&D). Bandung: Alfabeta, 2014.

[8] R. R. Hake, "Design-Based Research in Physics Education Research: A Review," unpublished

[9] S. Prabawanto, "Mathematics learning using realistic approach to increase students' mathematical problem solving and mathematical disposition," unpublished.

[10] E. Suherman, et al, Strategi Pembelajaran Matematika Kontemporer. Bandung: JICA, 2003.

[11] R. Arends, Learning To Teach (Belajar Untuk Mengajar). Yogyakarta: Pustaka Pelajar, 2008.

[12] A. Ahmadi, Psikologi Sosial. Jakarta: PT Rineka Cipta, 2007. 